演する予定である。

\section{0. 学会へご寄附}

明日山秀文氏より学会の基金にと，10万円のご寄附 をいただいた。

\section{1. 国際微生物連合会議}

第 1 回のサーキュラーができております。希望者は T 160 東京都新宿区信濃町 35, 慶応義熟大学矤学部

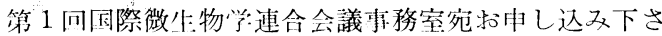
い。抄録提出は昭和 48 年 12 月 20 日締切りです。

なお，この会議への国立大学文部教官等の出席旅货 は，別枠として文部省から概算要求する予定である。 この件については，昭和 49 年 4 月頃备国立大学:に出 席旅費申請に関する通知がある予定であるから，その 時に必らず申請して拈くこと。

12. 植物ウイルス, 抗血清の入手について アメリカのATCCからリストが送られて来ました。 詳細はATCC の Mr. Jerry W. Blizzardに連絡して 下さい。住所は 12301 Parklawn Drive, Rockville, Maryland 20852, U.S.A.

\section{3. 第 7 回細菌病談話会開催のお知らせ}

日時：昭和 48 年 12 月 9 日（日）午前 10 時〜午後 5 時

場所：東京農工大学農学部（東京都府中市幸町） (国電中央線国分寺，京王線府中下車，バス でそれぞれ10 分, 5 分

話題および講演者：

\section{会報の訂正}

第 39 㥕 2 点

表紙ウラ 日次 23 行日

180 頁在，上小ら 13 行日

裹表紙 英文月次下から15行日

第 39 卷 3 号页

$$
\begin{gathered}
231 \text { 真有, 下から } 8 \text { 行日 } \\
232 \text { 而左, 上から } 5 \text { 行目 } \\
\text { " 左, 上から } 10 \text { 行目 } \\
\text { " 左, 上から } 17 \text { 行目 }
\end{gathered}
$$

1) インドネシアに拈りるィネの細菌病 中国農試 西沢正洋氏

2) クワ縮葉細囷病の発生尘態 甭，試 佐藤 守氏

3) 植物病原細菌の感染に対する微生物 の护抗現象

a) カンキツ潰瘳病藏の感染に対するPseudomonas sp. の拈扰

垓崎果樹試 太旧孝彦氏

b）イネ白葉枯病获の感染に対する 葉上細菌の怙抗

福井農試 伊阪実人氏

c）病原性の異なるイネ白葉枯病菌系 統問の相互作用について

北陸農試 安藤隆夫氏

d) 不親和吽:菌の前接種によるイネ白葉枯病 病斑拡大の抑制（スポットスピーカー）

北陸農試 堀野 修氏

世話人：東京農工大学農学部 渡辺実

Tel (0423) 64-3311 (代) 以線 402

本学会名举会員西門義一氏は昭和 48 年 8 月 26 日に，学会員武内晴好氏は9月11日，千葉修氏は 9 月 13 日，榎本鈴雄氏は 9 月 16 日に逝去されま した。慎しんで跕悼の意を竖します。
II:

都监11j

福织材

University

Uciversity

Koriyama

Fukushima

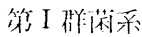

第留 I 莉采

がこの

ガンの

Xaw

Waw

黄玉

玉黄 